\title{
Plague in Iran: its history and current status
}

\author{
Abdolrazagh Hashemi Shahraki ${ }^{1,2}$, Elizabeth Carniel $^{3}$, Ehsan Mostafavi ${ }^{1,2}$ \\ ${ }^{1}$ Department of Epidemiology, Pasteur Institute of Iran, Tehran; ${ }^{2}$ National Reference Laboratory for Plague, Tularemia, and Q fever, Research \\ Centre for Emerging and Reemerging Infectious Diseases, Pasteur Institute of Iran, Akanlu, Kabudar-Ahang, Hamadan, Iran; ${ }^{3}$ Yersinia \\ Research Unit, National Reference Laboratory, Institut Pasteur, Paris, France
}

\begin{abstract}
OBJECTIVES: Plague remains a public health concern worldwide, particularly in old foci. Multiple epidemics of this disease have been recorded throughout the history of Iran. Despite the long-standing history of human plague in Iran, it remains difficult to obtain an accurate overview of the history and current status of plague in Iran.

METHODS: In this review, available data and reports on cases and outbreaks of human plague in the past and present in Iran and in neighboring countries were collected, and information was compiled regarding when, where, and how many cases occurred.

RESULTS: This paper considers the history of plague in Persia (the predecessor of today's Iran) and has a brief review of plague in countries in the World Health Organization Eastern Mediterranean Region, including a range of countries in the Middle East and North Africa.

CONCLUSIONS: Since Iran has experienced outbreaks of plague for several centuries, neighboring countries have reported the disease in recent years, the disease can be silent for decades, and the circulation of Yersinia pestis has been reported among rodents and dogs in western Iran, more attention should be paid to disease monitoring in areas with previously reported human cases and in high-risk regions with previous epizootic and enzootic activity.
\end{abstract}

KEY WORDS: Middle East, Iran, History of medicine, Yersinia pestis

\section{INTRODUCTION}

Plague is a life-threatening infectious disease that is still endemic in some areas around the world. It is caused by the bacillus Yersinia pestis, which was discovered in 1894 by Alexandre Yersin [1]. The natural reservoir of this disease is wild rodents, and the causative agent of the disease is transmitted to different animals and humans via infected fleas [2,3]. The most promi-

\section{Correspondence: Ehsan Mostafavi}

Department of Epidemiology, Pasteur Institute of Iran, 69 Pasteur Ave., Tehran 1316943551, Iran

Tel: +98-2166496448, Fax: +98-2189776655

E-mail: mostafaviehsan@gmail.com

Received: Jul 3, 2016, Accepted: Jul 24, 2016, Published: Jul 24, 2016

This article is available from: http://e-epih.org/

(C) 2016, Korean Society of Epidemiology

(C) This is an open-access article distributed under the terms of the Creative Commons Attribution License (http://creativecommons.org/licenses/by/4.0/), which permits unrestricted use, distribution, and reproduction in any medium, provided the original work is properly cited. nent infection vector for humans is the Xenopsylla genus, in particular X. cheopis. Living in rural areas, hunting or trapping animals, and keeping cats and dogs increase the risk of infection among humans [2]. The disease in humans exists in three clinical forms: bubonic, pneumonic, and septicemic. Without treatment, the mortality may be as high as practically $100 \%$, particularly for pneumonic plague [4].

As Y. pestis circulates at low levels in the rodent population in endemic foci of the disease [5], outbreaks are always possible, and a timely diagnosis is necessary for effective treatment $[4,6]$. Y. pestis has also been used in bioterrorism in the past and its usage in the future for such purposes is not difficult to imagine [7]. Studies have shown not only a trend of decreasing susceptibility to some antibiotics, but also the emergence of multi-drug-resistant strains [8,9], which underscores the need for plague to receive more attention as a significant public health concern than has previously been the case.

There have been three great world pandemics of plague. The first one, known as the Justinian plague, occurred in the Byzan- 
tine Empire (Constantinople) in the 6th century Common Era (CE) and spread through the Middle East, the Mediterranean, and Europe. The second pandemic, known as the Black Death, began in India, China, and some regions of Russia, and reached Western Europe in 1347 CE. The third pandemic was the Hong Kong epidemic that started in 1855 CE in Yunnan Province, China $[2,4]$. Y. pestis has been reported throughout the world, and plague is enzootic in rodents in Africa, North and South America, and Asia (the Middle East, Far East, and countries of the former Soviet Union) $[2,10,11]$. According to the International Health Regulations, the pneumonic form of the disease must be reported to the World Health Organization (WHO) immediately [12].

Some plague endemic foci still exist in central Asia; western Arabia (the Asir region); the Middle East, with a center in Iranian Kurdistan; central and southern Africa, and northwestern India [13-16]. Between 1987 and 2001, 36,876 confirmed cases of plague with 2,847 deaths were reported to the WHO [4, 15]. In 2013,783 cases were reported worldwide, resulting in 126 deaths [17]. In recent years, more than $95 \%$ of human cases have been reported in Africa, mainly in Madagascar [18]. Plague has a seasonal pattern in most endemic areas, which is associated with the predominant vectors and rodent reservoirs and their ecology in specific geographical niches [4]. In the beginning of the 1990s, plague was believed to have been eliminated due to the paucity of reported cases. However, in 1994, India experienced a large outbreak of pneumonic plague after 30 years with no reports of the disease [13], and in 2003, an outbreak of plague was reported in Algeria, in an area considered plague-free for 50 years [14]. The reemergence of plague was reported in Libya in 2009, after 25 years without a case of plague [19]. In August 2013, in a region of Kyrgyzstan bordering Kazakhstan, a case of bubonic plague was reported [20].

Plague is one of the oldest infectious diseases in Iran, and has had devastating effects on the human population of Iran throughout history. Our understanding of plague pandemics has rapidly expanded in the last decade, largely due to molecular approaches, but much remains to be understood regarding past plague epidemics in various parts of the world, particularly in Iran, as Persia was the greatest empire in the Middle East for much of its history.

The region of Kurdistan, north of the Zagros Mountains in Iran and stretching across southern Turkey and the north of Iraq and Syria, is considered one of the most significant endemic foci of plague worldwide [21-25].

This review considers the history of plague in Persia (the predecessor of today's Iran) and incorporates a brief review of the countries in the WHO Eastern Mediterranean Region, consisting of several countries in the Middle East and North Africa that have frequently experienced plague outbreaks in recent deca- des, including Afghanistan, Bahrain, Iraq, Jordan, Kuwait, Lebanon, Saudi Arabia, Syria, United Arab Emirates, Yemen, Egypt, Libya, Morocco, and Tunisia.

\section{GEOGRAPHY OF PERSIA/IRAN}

Historically, the territory of the Persian Empire encompassed all of today's Iran, Iraq, Lebanon, Jordan, Armenia, Turkey, and Syria, as well as parts of Saudi Arabia, Afghanistan, Pakistan, the Caucasus, Central Asia, and Egypt.

Iran is a Middle Eastern country, located south of the Caspian Sea and north of the Persian Gulf and Gulf of Oman. It shares borders with Iraq, Turkey, Azerbaijan, Turkmenistan, Armenia, Afghanistan, and Pakistan. With an area of 1,648,000 km (636,000 square miles), Iran ranks eighteenth in size among the countries of the world. Iran has a variable arid climate, in which most of the relatively scant annual precipitation falls between October and April. Seven percent of the country is forested.

\section{PLAGUE IN IRAN}

Historical records show that plague has been active in Iran for centuries; however, insufficient information, invalid documentation, the misclassification of plague as a different infectious disease such as cholera, and the way in which plague has interacted with social dynamics have hindered the analysis of plague outbreaks over time.

Plague frequently recurred in Iran throughout history, but the dating and characterization of the nature of plague outbreaks remain imprecise. The rapid expansion of plague with high mortality rates may have been related to sparse treatment centers, a poor public health system, the absence of effective quarantine arrangements, washing the dead bodies in rivers before burial, and transferring corpses to sacred places such as Mashhad, Qom, Najaf, and Karbala [26]. Plague epidemics in Iran typically originated from villages or places with poor hygiene, and rural epidemics have been found to last for periods of 30 to 40 years with no officially reported cases [27]. Throughout the course of history, almost all regions of the country, especially near the borders (in the north, south, east, and west) have reported plague outbreaks (Figure 1,Table 1).

In $543 \mathrm{CE}$, plague reached what is now modern Iran after passing from Italy to Syria, Palestine, and Iraq, and infected the Persian imperial army and the population at that time [28]. In $544 \mathrm{CE}$, the plague infected the army of the Roman Empire and the army of the Persian Empire at a time when they were at war [29]. In $627 \mathrm{CE}$, a large epidemic of plague, which led to the death of more than 100,000 people in Ctesiphon, the Sas- 


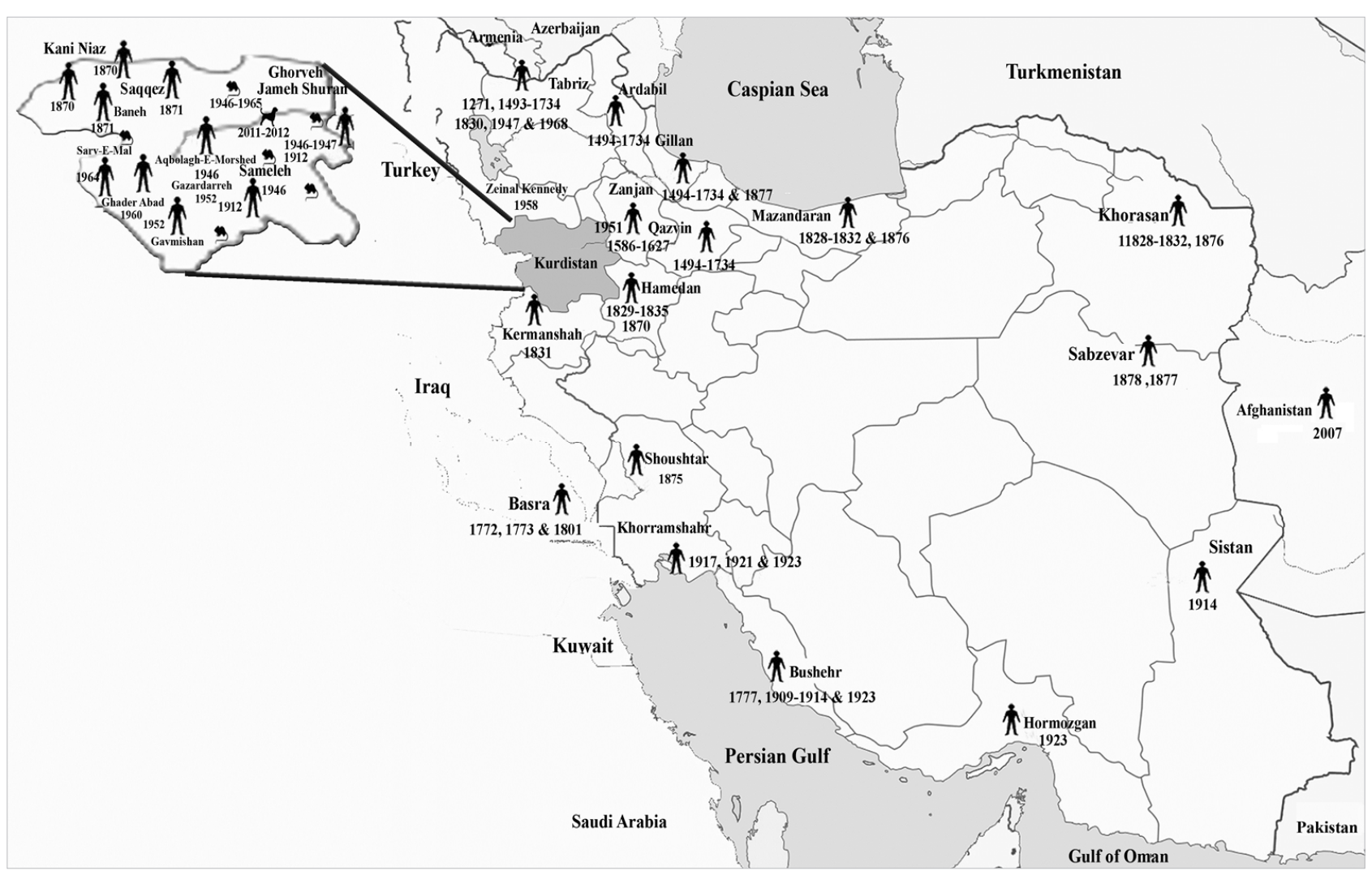

Figure 1. Areas affected by plague throughout the history of Iran. Kurdistan, known to be the focus of plague in Iran, has been drawn larger.

sanian capital, close to Baghdad, was reported. Shortly thereafter, Shiroyeh, the king of Persia, died of plague [30]. Another plague epidemic occurred from 634 to $642 \mathrm{CE}$ in the region of Yezdigird III, the 'great king' of Persia [31].The Yezdigird Plague may be another name for the plague epidemic in Syria and Palestine that is known as the Amwas (or Amawas) Plague, which killed almost 25,000 people in 638 or 639 CE [32]. The Amwas Plague is considered one of the numerous outbreaks of plague in the sixth, seventh, and eighth centuries that followed the major pandemic of the sixth century, the Justinian Plague [33]. In 688-689 CE, a devastating plague swept through Basra and killed 70,000 to 73,000 people [31]. The Persian Empire experienced considerable damage from plague outbreaks to both its population and its military. Its weakened military strength is considered a factor contributing to the inability of Persia to prevent the Arab conquest of its territory [34].

To the best of our knowledge, no concrete documentation exists of plague outbreaks and the impact of the plague on Persia between 689 and $1270 \mathrm{CE}$; it seems, though, that plague continued to spread throughout Persia, remaining endemic after the outbreaks of 689 until the middle of the thirteenth century. Ali ibn al-Abbas al-Majusi (933-1000 CE) described plague in his medical book titled Kitäb al-Malakiyy. Abu Sahl 'Isa ibn Ya- hya al-Masihi al-Jorjani (960-1000 CE) wrote an article about plague; and, interestingly, the Canon of Medicine of Avicenna (980-1037 CE) noted the clinical signs of bubonic plague and Esmail Jorjani (1042-1137 CE) mentioned inguinal lymphadenopathy as a sign of bubonic plague [35].

Marco Polo, the famous Italian merchant traveler, reached the city of Tabriz, in northwestern Iran, in 1270 and in The Travels of Marco Polo, he mentioned that the city gates were closed due to the plague [36].

Several outbreaks of human plague occurred during the Safavid period (1495-1735 CE), affecting areas in northern Iran such as Gilan, Tabriz, Qazvin, and Ardabil. Another outbreak occurred in Qom, another city in the north, which continued for five years with 12,000 deaths. After the collapse of the Safavid Dynasty and the occupation of Iran by Afghan invaders, another plague outbreak was recorded in Gilan in $1727 \mathrm{CE}$. In $1731 \mathrm{CE}$, approximately 20,000 people died due to a plague outbreak in Hamadan and the western region of Iran [37].

In the epidemics of 1772-1773 CE in Iran, quarantine practices were introduced into the Persian Gulf region for first time [38]. This outbreak is recorded as one of the most severe epidemics of plague, killing an estimated two million people in Persia (Iran) and Persian-controlled lands to the west. Plague 
Table 1. Plague outbreaks in Iran during the 19th and 20th centuries

\begin{tabular}{|c|c|c|c|c|c|}
\hline Outbreak area & Province & Location in Iran & Year & $\begin{array}{l}\text { No. of mortalities } \\
\text { (no. of case) }\end{array}$ & Reference \\
\hline Caspian sea littoral & ND & North & $1829-1833$ & ND & 45 \\
\hline ND & Khorasan & Northeast & $1829-1833$ & ND & 45 \\
\hline $\begin{array}{l}N D \\
N D \\
N D\end{array}$ & $\begin{array}{l}\text { Kurdistan } \\
\text { Kermanshah } \\
\text { Hamadan }\end{array}$ & West & $1829-1835$ & Thousands & $\begin{array}{l}27 \\
27 \\
27\end{array}$ \\
\hline $\begin{array}{l}\text { Rasht } \\
\text { ND }\end{array}$ & $\begin{array}{l}\text { Gilan } \\
\text { Mazandaran }\end{array}$ & North & $\begin{array}{l}1830-1831 \\
1830-1831\end{array}$ & $\begin{array}{c}\text { 40,000 (in Rasht) } \\
80,000 \text { (in Barforoosh) }\end{array}$ & $\begin{array}{l}41 \\
40\end{array}$ \\
\hline ND & Azerbaijan & Northwest & $1830-1831$ & 30,000 (in Tabriz) & 26,38 \\
\hline $\begin{array}{l}\text { Saghez, Baneh } \\
\text { Serin Bulagh }\end{array}$ & Kurdistan & West & 1871 & Thousands & 42,43 \\
\hline Shushtar & Khuzestan & Southwest & 1876 & 1,800 & 41 \\
\hline Sabzevar & & & $\begin{array}{l}1877 \\
1878\end{array}$ & $\begin{array}{l}37 \\
\text { Thousands }\end{array}$ & $\begin{array}{l}26 \\
27\end{array}$ \\
\hline Rasht & Gilan & North & 1877 & ND & 41,42 \\
\hline Bushehr & Bushehr & South & 1877 & ND & 47 \\
\hline ND & Kermanshah & West & 1877 & ND & 47 \\
\hline ND & Khorasan & Northeast & 1877 & ND & 42 \\
\hline Persian Gulf region & ND & South & 1899 & ND & 45 \\
\hline Around Sistan Lake & Sistan and Baluchestan & East & 1906 & 1,409 & 44 \\
\hline Bushehr & Bushehr & South & $\begin{array}{c}1910 \\
1911 \\
1912-1913\end{array}$ & $\begin{array}{c}66 \\
98 \\
725(965)\end{array}$ & $\begin{array}{l}44,45 \\
44,45 \\
44,45\end{array}$ \\
\hline ND & Kurdistan & West & 1913 & ND & 22 \\
\hline Torbat-e Jam & Khorasan & Northeast & 1913 & ND & 22,45 \\
\hline $\begin{array}{l}\text { Bandar Lengeh } \\
\text { Bandar Abbas }\end{array}$ & Hormozgan & South & $\begin{array}{l}1914 \\
1915\end{array}$ & $\begin{array}{l}0(1) \\
0(3)\end{array}$ & $\begin{array}{l}48 \\
48\end{array}$ \\
\hline $\begin{array}{l}\text { Khorramshahr } \\
\text { Khorramshahr } \\
\text { Abadan }\end{array}$ & Khuzestan & Southwest & $\begin{array}{l}1915 \\
1917 \\
1917\end{array}$ & $\begin{array}{c}0(3) \\
43(79) \\
409(481)\end{array}$ & $\begin{array}{l}45 \\
45 \\
45\end{array}$ \\
\hline $\begin{array}{l}\text { Torbat-e Jam } \\
\text { Kariz }\end{array}$ & Khorasan & Northeast & 1921 & ND & 24,45 \\
\hline Khorramshahr & Khuzestan & Southwest & 1922 & ND & 48 \\
\hline Chabahar & Sistan and Baluchestan & East & 1923 & ND & 48 \\
\hline Khorramshahr & Khuzestan & Southwest & 1923 & $45(71)$ & 48 \\
\hline Abadan & Khuzestan & Southwest & 1923 & $409(481)$ & 48 \\
\hline Bandar Lengeh & Hormozgan & South & 1923 & $0(4)$ & 48 \\
\hline Khorramshahr & Khuzestan & Southwest & 1924 & $115(152)$ & 44,48 \\
\hline Abadan & Khuzestan & Southwest & 1924 & $0(233)$ & 44,48 \\
\hline Genaveh & Bushehr & South & 1924 & $14(17)$ & 48 \\
\hline Bandar Abbas & Hormozgan & South & 1924 & $7(12)$ & 48 \\
\hline Bushehr & Bushehr & South & 1924 & $0(1)$ & 48 \\
\hline Bandar Lengeh & Hormozgan & South & 1924 & $0(1)$ & 48 \\
\hline Aghbolagh Morshed & Kurdistan & West & 1947 & 56 & 45 \\
\hline Sameleh and Sarbaghleh & Kurdistan & West & 1947 & 17 & 45 \\
\hline MazidAbad & Kurdistan & West & 1951 & 2 & 45 \\
\hline Gozar-darreh & Kurdistan & West & 1952 & 45 & 45 \\
\hline Gavmichan & Kermanshah & West & 1952 & 8 & 45 \\
\hline ZenalKandi & Western Azerbaijan & Northwest & 1958 & 6 & 45 \\
\hline Ghaderabad & Kurdistan & West & 1961 & 7 & 45 \\
\hline Sarumal & Kurdistan & West & 1963 & 14 & 45 \\
\hline SeyyedAbad & Kurdistan & West & 1966 & 1 & 45 \\
\hline
\end{tabular}

$\mathrm{ND}$, not determined. 
was introduced to Baghdad, today the capital of Iraq, in the winter of 1772 and reached Basra in 1773. The plague killed more than 250,000 people in Basra alone. A thousand deaths were recorded daily, and the disease spread to Bombay, India [38]. Plague also spread southward along the Persian Gulf to Bushehr, expanding over most parts of Persia and reaching Bahrain in 1773 [38]. In 1798, a small outbreak of the plague was recorded in Mosul [38].

In 1800, a plague outbreak started in the city of Mosul, northern Iraq, and spread to Baghdad and Istanbul. The authorities introduced quarantine measures to prevent the spread of the plague to India. During this wave, the workers of the British East India Company were moved to a village outside Basra. This led to no reports of plague among European residents [38].

In 1830, an epidemic of plague affected the entire Persian Gulf region. The disease began in the fall of 1830 with an outbreak in Tabriz, northern Iran, which led to the death of 30,000 people and the relocation of the Iranian capital from Tabriz to Ardabil $[26,38]$. In 1831, the disease reached northern Iran and lead to the death of thousands of people in Mazandaran and Gilan (Rasht) [26]. This plague outbreak reduced the population of Rasht from 60,000 to 15,000-20,000 [26,39].

A plague epidemic in western Iran, in the Kurdistan, Kermanshah, and Hamadan regions, led to thousands of deaths from 1829 to 1835 and in 1870 [27]. In 1876, a plague epidemic in Shushtar, southwestern Iran, led to 1,800 deaths out of a population of 8,000 within only a few months [40]. The plague was again reported in Gilan and had a significant negative impact on the economy [41]. An outbreak of plague in villages including Serin Bulagh, Saghez, and Baneh in Kurdistan, western Iran, killed hundreds of people $[42,43]$. At the time, Italian doctors came from Istanbul to provide assistance with the plague epidemic in Persia [44]. Moreover, in 1877, plague recurred around Khorasan, eastern Iran, and around the Caspian Sea [42].

Mohammad Razi Tabatabai, the senior physician of the army during the reign of King Naser al-Din Shah Qajar wrote a book on plague in 1875 , in which he described the medical practices of the time and discussed control strategies for plague [45]. Between 1870 and 1882, Dr. Theodorides documented the places in Kurdistan where plague commonly occurred, and noticed certain villages to be foci of the disease in this region [46].

A plague epidemic in a village north of Sabzevar, Khorasan Province in northwest Iran killed 37 individuals in 1877 [26]. Another epidemic in 1878, in two neighboring villages in Khorasan, left hundreds dead [27].

In 1877, an epidemic of the disease was again reported in the cities of Rasht, Bushehr, and Kermanshah. Following that, a devastating epidemic occurred in the regions around the Persian Gulf; as a result, British forces founded the first quarantine center on Hengam Island, Bushehr, to prevent further transmis- sion of the disease to other points of the country [47].

The plague epidemic in 1906 in the province of Sistan and Baluchestan, southeastern Iran, was restricted to the regions around Sistan Lake, and it is believed that the infection was transmitted to this area via old clothes imported from India [44].

During the plague epidemics between 1910 and 1911 in Bushehr, in southern Iran, people fled the city, leading to a negative economic impact [44]. In 1912 and 1913, the plague reemerged in Bushehr; 750 people died and 4,000 vaccinations were conducted at that time. Bushehr was then spared from the disease until 1924 when the next outbreak occurred [44]. Most cases of the disease in the Persian Gulf region happened in the first quarter of the 20th century, and there is a high probability that the disease originated from India [41,49].

In 1913, outbreaks were seen in two provinces in Iran: one in Kurdistan in the west, and the other in Khorasan, in the east [22]. A plague outbreak was reported in Khorramshahr and Abadan, in southwestern Iran, in 1924 [44]. The disease reemerged in Torbat-e Jam, in Khorasan, after eight years without a reported case [24].

Some of the plague outbreaks occurred in the area where the Anglo-Persian Oil Company, an English company, was actively extracting petroleum in the southern part of the country. The measures that were taken by this company had a great impact on the control of plague in the area. In 1925, plague vaccination started in the southern areas of Iran and 4,553 individuals were vaccinated. Houses were disinfected and with any new report of the disease, serious actions were taken, such as disinfection of all clothing, isolation of the patient, destruction of the house (with recompense), and prohibition of rebuilding on that spot [38].

\section{PLAGUE IN IRAN OVERTHE LAST CENTURY}

Plague was not reported again for 23 years until an outbreak in Kurdistan, western Iran, in 1947 [24]. Due to the presence of the appropriate species of wild rats and fleas in Kurdistan, this region had become an endemic area for plague. In these natural foci, different species of rodents are present, of which the Meriones genus, including M. libycus, M. persicus, M. vinogradovi, M. tristrami, plays an important role in the persistence of plague. The latter two species are extremely sensitive to the causative agent of the disease, whereas the first two are resistant. The presence of plague in Kurdistan thus depends on the ecological interplay between susceptible and resistant rodent species living in close contact. Along with these species, other types of rodents are present, such as Microtus, Mesocricetus, Allactaga and Cristolus; these rodents are less frequently found and play a minor role in the epizootic evolution of the region [24]. In 1953, a re- 
search center was founded in the village of Akanlu, $100 \mathrm{~km}$ northwest of Hamadan and on the border of Kurdistan; this center was opened to conduct research on plague and has since been in operation as a surveillance center for plague in western Iran. In that center, Karimi [50] concluded that the plague bacterium can survive in soil for several months.

Marcel Baltazard, the former director of the Pasteur Institute of Iran, and his Iranian colleagues studied 14,102 rodents in this region in 1966 and 1967, and found 66 infected rodents [24]. During this time, nine outbreaks of plague were reported, mostly in Kurdistan, with 156 reported deaths. Evidence showed that outbreaks of bubonic plague in this area, where no domestic rodents are present, were due to inter-human transmission by the flea Pulex irritans, starting with rare cases of plague contracted in the fields. Such instances of inter-human transmission of plague, originating in villages, tend to die out rapidly due to the sparse population of the villages, the long distances between them, and the paucity of means of communication. However, when imported into an urban area with a denser human population, plague can immediately become the terrifying disease it was during the Middle Ages [24]. The last formally reported outbreak of human plague in Kurdistan was in 1966 [51].

A major discovery resulting from the studies of these researchers in Kurdistan was the concept of burrowing plague [52]. It was shown that $Y$. pestis could remain alive for several years in the burrows of dead rodents, and then re-infect the new rodents colonizing these empty burrows. In addition to the well-established rodent-flea-rodent cycle, they demonstrated the existence of the burrow-rodent-burrow cycle, allowing the inter-epizootic maintenance of the plague bacillus in its endemic foci [53].

The surveillance of regions surrounding the plague focus in Kurdistan, involving the study of wild rodents, revealed the existence of an epizootic center in Sarab in eastern Azerbaijan Province, north of Kurdistan, where plague had not yet been reported [25]. In this region in 1976, fourteen samples of Y. pestis were isolated from wild rodents (M. Persicus, M. vinogrado$v i$, and Mesocricetus brandti) and from their fleas (Xenopsylla conformis and Nosopsylla iranus iranus) [25].

The surveillance of plague in Kurdistan by the Pasteur Institute of Iran revealed that the disease remained silent for a period of between three to five years in its natural foci and then reappeared in its rodent hosts $[21,54,55]$.The same finding was reported from different parts of the world, including India, Brazil, Argentina, South Africa, and the US [56]. It is clear that the disappearance and reappearance of plague after several years is multifactorial, very complex, and depends on the interactions of its components (rodents, vectors, ectoparasites), population density, life cycles, the geographical distributions of the components, the season, rains, saturation, temperature, and local and global climate fluctuations [57,58].
The monitoring of plague continued from 1978 to 2001 through the Research Center for Emerging and Reemerging Infectious Diseases, located in Akanlu village in Hamadan. It concentrated on monitoring the disease in rodents, and positive rodents and/or fleas were identified. According to studies of the Pasteur Institute of Iran surveillance team during the Iran-Iraq war (1980-1988), in the areas affected by war, no Y. pestis infections were observed in the 1,800 rodents and 36,000 fleas monitored [59].

A recent study in 2011 and 2012, conducted at the Research Center for Emerging and Reemerging Infectious Diseases (Akanlu), of the border area between Kurdistan and Hamadan provinces showed that $1.02 \%$ of the rodent population and $3.42 \%$ of dogs were positive for the antibody against the bacteria, implying that this focus is still active [16].

Because most cases of plague outbreaks occurred before the emergence of microbiology, both the history and the historical population structure of $Y$. pestis are difficult to characterize. Using molecular biology technology on the few available strains from Iran and Kurdistan revealed that all isolates belonged to the Medievalis biovar [60], indicating that they are of Asian origin and are not from the third pandemic. The Orientalis biovar, as the causative agent of the third pandemic, was widespread and has been reported in Turkey [60,61], the northwestern neighbor of Iran. Further investigation using ancient DNA technology $[62,63]$ and studying the population structure of Y. pestis in Iran and its neighboring countries will hopefully supply strong evidence to fill the gaps on how the bacterium entered and circulated in Persia (Iran), and which biovar and genotypes of $Y$. pestis affected this region.

\section{PLAGUE INTHE MIDDLE EAST AND NORTH AFRICA}

It is clear that plague frequently recurred in the Middle East and North Africa for over half a millennium, but the dating and the characterization of the nature of the plague outbreaks are fairly imprecise. Nevertheless, an attempt has been made to describe the periodicity and nature of recurrences of plague. The rapidity and the severity of these outbreaks raise the question of the endemicity of plague in this region.

Roughly over the past century, plague outbreaks have been seen in at least 14 countries in theWHO Eastern Mediterranean Region in the Middle East and North Africa (Figure 2); all of these, as well as many earlier outbreaks, are briefly reviewed below.

\section{Afghanistan}

The WHO Expert Committee on Plague determined plague to be endemic in Afghanistan in its report in 1953 [64]. Enzo- 


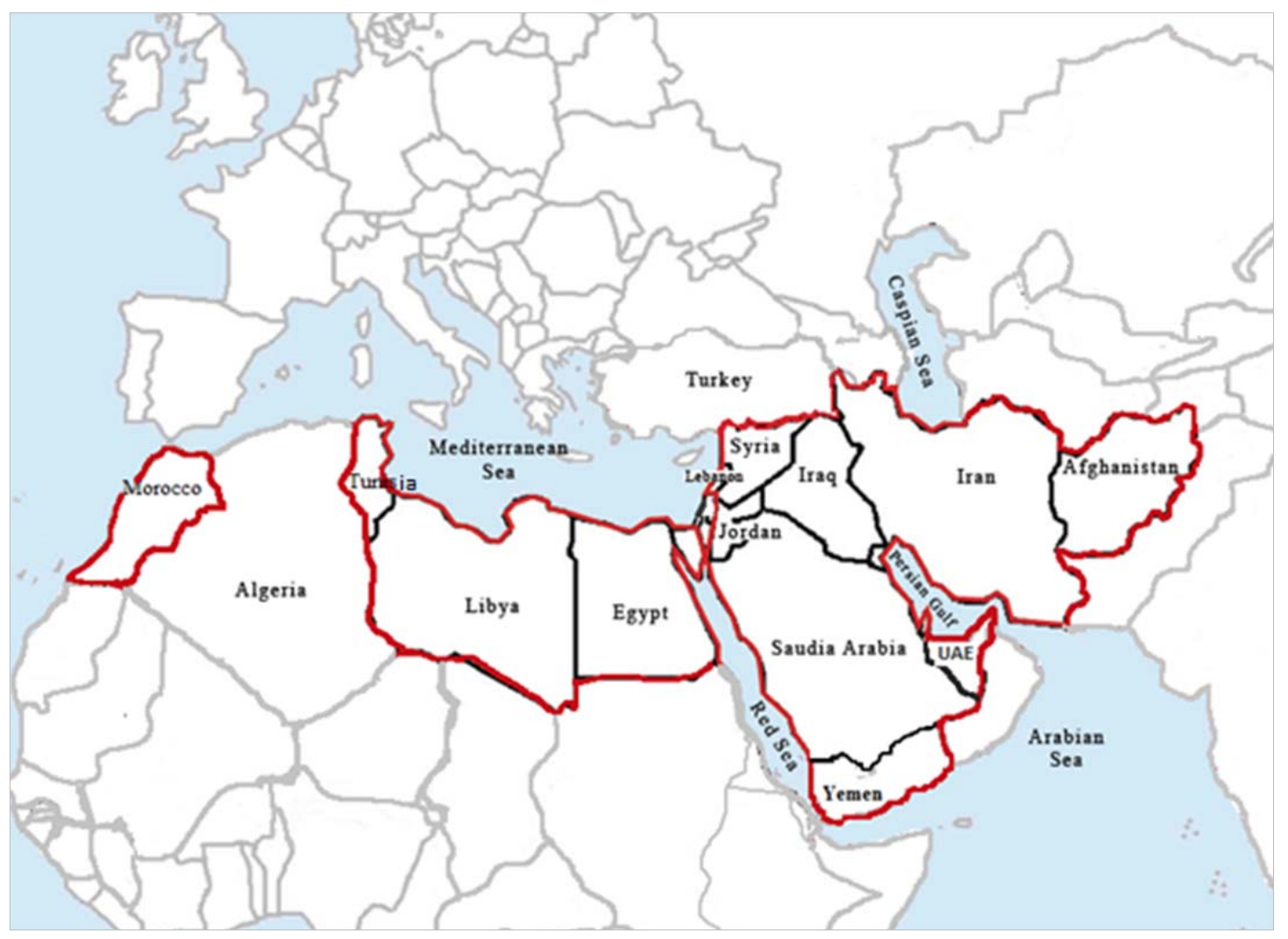

Figure 2. Countries in the World Health Organization Eastern Mediterranean Region affected by plague.

otic sylvatic rodent plague is endemic in the northeast (Badakshan, Konar) along the Pakistani border; isolated cases of human bubonic plague have occurred, particularly along the Pakistani border. Meriones spp. (gerbils) and various Microtinae (meadow mice) are sylvatic reservoirs of plague in this region [65]. In late 2007, an outbreak of plague with acute gastroenteritis symptoms occurred in Nimruz Province in southern Afghanistan; in this outbreak, 17 of the 83 infected cases died, and consumption of infected camel meat was diagnosed as the source of infection [66].

\section{Bahrain}

In $1529 \mathrm{CE}$, an outbreak of plague occurred in Bahrain; leading to the failure of a Portuguese attack on this region. A plague epidemic in the Arabian littoral also affected Bahrain in 1773 [38,67,68]. From 1907 to 1914, two other epidemics of bubonic plague were reported in this area [67]. In 1914, 1915, and 1924, imported cases of plague were also reported in Bahrain [48].

Iraq

Throughout its history, Iraq has experienced multiple epidemics of plague [69]. In 716 and $717 \mathrm{CE}$, a large outbreak known as al-Ashraf (the Notables) was recorded in Iraq and Syria [70].
In an epidemic of bubonic plague in 1772 and 1773, many victims died in cities such as Basra (with 250,000 deaths) and Mosul. In $1801 \mathrm{CE}$, a large plague epidemic occurred in Mosul and Baghdad [38,71]. A plague epidemic occurred again in Baghdad in 1908 [33]. From 1923 to 1924, approximately 90 cases of pneumonic plague were reported in Baghdad, and some plague outbreaks were reported in Basra [48,72].

\section{Jordan}

Plague in Jordan was first seen in the seventh century [23]. In 1997, an outbreak of bubonic plague was reported in northeastern Jordan, and all affected cases recovered from the disease. Two dogs tested serologically positive. All cases were infected through the consumption of camel meat [73].

\section{Kuwait}

The plague outbreak of 1773 CE in Iraq spread to Kuwait, leading to an outbreak in this region [68].

\section{Lebanon}

This country has been affected by plague in a variety of ways over the ages and has played a significant role in transmitting the disease to other parts of the world. The plague epidemic in 
Marseille, France, in 1720 led to 50,000 deaths and occurred via transmission of the infection by a ship from Lebanon [33]. In 1900 , four cases of plague were reported in Beirut. This outbreak took place after 65 years with no reported cases [70].

\section{Saudi Arabia}

This country has experienced several outbreaks of plague in the past [33]. An outbreak of plague took place in $1773 \mathrm{CE}$ in the al-Qatif region, an area located in the eastern part of Saudi Arabia [68]. In 1897 and 1898, several fatal cases of plague were reported in Mecca. In 1899, only two cases, both originating in Jeddah, were observed in Mecca [74]. In 1994, five cases of bubonic plague were reported in Goriat, a city located in the desert in southern Saudi Arabia with one reported death. The source was consumption of an infected camel's liver [75]. The presence of plague in wildlife and domestic animals is confirmed in this country, and this should be considered a potential risk for the general population as well as for Hajj pilgrims [76].

\section{Syria}

The circulation of plague among Syria, Palestine, and Egypt occurred regularly throughout history [77,78]. Accordingly, data related to plague in these three regions have commonly been reported together [70,79]. Outbreaks between 541 and $749 \mathrm{CE}$ in these regions were related to regional trading and the disease was transmitted into Syria via ships entering from Egypt [78]. An outbreak in $746 \mathrm{CE}$ occurred due to a military attack on Constantinople, in which soldiers used swords contaminated with plague [80].

\section{United Arab Emirates}

In 1914 and 1924, imported cases of plague were reported in Dubai [48].

\section{Yemen}

The oldest recorded case of human plague in Yemen occurred near the border with Saudi Arabia, in Asir Province, in 1815, and is believed to have spread to Jeddah and Mecca [81]. Since the 1815 outbreak in this area, few outbreaks have been reported, perhaps due to the lack of investigation. A plague outbreak was reported in Khawlan in the northern highlands of Yemen in 1969 and left 15 dead in two villages [82]. The isolation of Y. pestis confirmed the nature of this outbreak in 1969.

\section{Egypt}

In $1347 \mathrm{CE}$, plague reached Alexandria in Egypt, most likely through the port's trade with Constantinople and ports on the Black Sea [83]. Between 1347 and 1517, Egypt experienced more than twenty outbreaks. In an outbreak in 1581, approximately 500,000 people died of plague [35]. In the plague pan- demic in the sixth century, more than 900,000 cases in Egypt and 22,000 cases in Gaza (Palestine), which was under the authority of Egypt at that time, were reported [80]. In a large outbreak in 1835, approximately 33,000 people died. In 1899, after a period of 50 years with no reported cases, plague recurred in Egypt, and between 1899 and 1919, approximately 15,000 cases of human plague were reported $[35,84]$. The coexistence of the Nile rat, Arvicanthis niloticus, and ectoparasites in combination with trade with Asia, Africa, and the Mediterranean, as well as the Nile floods, suggests that it is possible that Y. pestis was primarily a disease of the Nile rat, indicating that Egypt may have been the most probable point of origin of bubonic plague as an epidemic disease [85]. In 1940, 452 cases were reported in Assiut province and some cases were also reported in Port Said. In 1943, an outbreak was observed in the Suez Canal area; and in the Ismailia district and Port Said in 1944 accounting for a total of 862 cases. In 1945, plague caused 19 cases in ports along the canal. In 1947, a 15-case outbreak took place in Alexandria and was the last reported outbreak in Egypt [86]. The reemergence of plague in Egypt should not be excluded, due to the presence of suspected potential natural foci and global climate change.

\section{Libya}

Between 1913 and 1920, multiple outbreaks occurred in Libya, with the largest taking place in 1917 in Benghazi, where 1,449 people died of plague [87]. Twelve confirmed cases were noted in 1939 to 1943 in a locality $12 \mathrm{~km}$ from Tripoli [86]. Small outbreaks occurred in 1972, 1976, 1977, and 1984 near Tobruk, close to the border with Egypt. In 2009, after 20 years with no reported cases, the reemergence of plague was observed. Three members of a family were infected with the septicemic form and one of them died. This outbreak was of Asian origin $[88,89]$. Another possible outbreak of plague comprising more than 20 cases occurred at Tobruk during the Libyan revolution in May 2011 [86]. These data suggest that plague has active foci in Libya.

\section{Morocco}

The first plague cases reported in Morocco were in 1909 among 25 military stations in Casablanca. A severe epidemic with 8,000 to 10,000 deaths took place in 1911. Between 1940 and 1945, almost 5,400 cases were reported in Morocco in the regions of Chaouia, Agadir, Marrakech, Rabat, Doukkala, and Port Lyautey $[86,90]$. Another large outbreak of plague occurred in 1977 , in which almost 50,000 people died [91].

\section{Tunisia}

Plague has not been very prevalent in Tunisia [92], although plague epidemics occurred in Tunisia from 1870 to 1900 . Two 
major plague epidemics also struck Tunisia in 1784 and 1818, which lasted for months [93]. Variable susceptibility to plague has been reported among the flea and rodent species in Tunisia [94]. Twelve cases were reported in 1940 and one in 1941 [86]. A plague outbreak was recorded in 1944, in which 64 people were infected with 27 deaths [95].

\section{CONCLUSION}

According to the WHO Expert Committee on Plague (1959) [96], and field investigations [20,21,53,54], Iranian Kurdistan remains an active plague focus. Recent surveillance in 2011 to 2012 likewise demonstrated that plague is active in this area [16]. Investigations in Turkey, Syria, and Iraq failed to confirm the existence of plague in wild rodents, but an isolated human plague strain in Turkey near the Syrian border [97], with the same biochemical character as the Iranian strains, supports the view that all these foci form part of a large enzootic area [98].

Almost all of the countries in the Middle East and North Africa have reported human plague outbreaks, although less focus has been placed on epidemics of plague in wildlife. In the last 50 years, human plague outbreaks have been reported in Saudi Arabia [75,76], Afghanistan [65,66], Libya [88,89], Morocco [91],Algeria [99,100], and Jordan [73].

The presence of exemplary studies on the wildlife population in Iran may be due to the existence of a research center founded in 1952 as part of the Pasteur Institute of Iran; at this center, extensive studies have been carried out on rodents and other animal hosts of $Y$. pestis in Iran.

Comprehensive studies of locations with historical records of human plague could help clarify the current status of the disease in this region. Otherwise, without adequate knowledge and preparation, human plague outbreaks are expected to continue.

The lack of reports of human plague over the past 50 years does not necessarily imply that the disease has not occurred among humans in Iran. Since Iran has experienced outbreaks of plague for several centuries, neighboring countries have reported the disease in recent years, the disease can be silent for decades, and the circulation of Y. pestis has been observed among rodents and dogs in western Iran, more attention should be paid to disease monitoring in areas with previously reported human cases and in high-risk regions with previous epizootic and enzootic activity. Plague should be more strongly emphasized in the medical education system in Iran. It is highly recommended that general practitioners and healthcare workers obtain adequate knowledge of the natural cycle of Y. pestis and the clinical signs of plague in order to help them identify the disease. Moreover, further studies are needed to better clarify the epidemiology of plague in Iran.

Finally, the following suggestions may be made to improve the surveillance of plague in Iran: 1) Health staff and practitioners in areas with prior outbreaks of plague, as well as in the eastern and western border areas of Iran, should be trained to be aware of this disease. 2) A standard protocol should be designed for preparing and dispatching suspected samples from all over the country to the Pasteur Institute of Iran. 3) Educational materials on plague in the form of pamphlets, seminars, and conferences concerning zoonotic diseases should be prepared and disseminated. 4) The Research Center for Emerging and Reemerging Diseases of the Pasteur Institute of Iran (Akanlu) should be equipped and empowered as the main center of surveillance, research, and education about plague and other emerging and reemerging diseases in Iran.

\section{ACKNOWLEDGEMENTS}

We appreciate the financial support of the Pasteur Institute of Iran and the Center for Disease Control of the Iranian Ministry of Health and Medical Education (grant no. 810). We also would like to thank Mr. Behzad Pourhossein, who helped us in the first phase of data collection of this study.

\section{CONFLICT OF INTEREST}

The authors have no conflicts of interest to declare for this study.

\section{ORCID}

Abdolrazagh Hashemi Shahraki http://orcid.org/0000-00031852-194X

Elizabeth Carniel http://orcid.org/0000-0002-7410-9397

Ehsan Mostafavi http://orcid.org/0000-0002-1997-517X

\section{REFERENCES}

1. Bendiner E. Alexandre Yersin: pursuer of plague. Hosp Pract (Off Ed) 1989;24:121-128.

2. Perry RD, Fetherston JD. Yersinia pestis--etiologic agent of plague. Clin Microbiol Rev 1997;10:35-66.

3. Slack P. The black death past and present. 2. Some historical problems. Trans R Soc Trop Med Hyg 1989;83:461-463.

4. World Health Organization. Emergencies preparedness, response: plague manual: epidemiology, distribution, surveillance and control [cited 2016 Aug 5]. Available from: http://www.who.int/csr/resources/publications/plague/WHO_CDS_CSR_EDC_99_2_EN/en/. 
5. Duplantier JM, Duchemin JB, Chanteau S, Carniel E. From the recent lessons of the Malagasy foci towards a global understanding of the factors involved in plague reemergence. Vet Res 2005;36:437453.

6. Salkeld DJ, Salathé M, Paul Stapp P, Jones JH. Plague outbreaks in prairie dog populations explained by percolation thresholds of alternate host abundance. Proc Natl Acad Sci U S A 2010;107:1424714250 .

7. Riedel S. Plague: from natural disease to bioterrorism. Proc (Bayl Univ Med Cent) 2005;18:116-124.

8. Welch TJ, Fricke WF, McDermott PF, White DG, Rosso ML, Rasko DA, et al. Multiple antimicrobial resistance in plague: an emerging public health risk. PLoS One 2007;2:e309.

9. Rasoamanana B, Coulanges P, Michel P, Rasolofonirina N. Sensitivity of Yersinia pestis to antibiotics: 277 strains isolated in Madagascar between 1926 and 1989. Arch Inst Pasteur Madagascar 1989;56: 37-53 (French).

10. Christie AB, Corbel MJ. Plague and other yersinial diseases. In: Topley WW, Wilson GS, Parker MT, Collier LH, editors. Topley and Wilson's principles of bacteriology, virology and immunology. 8th ed. London: Edward Arnold; 1990, p. 399-421.

11. Butler T. Plague and other Yersinia infections. New York: Plenum Medical Book; 1983, p. 29-55.

12. Heymann DL. Control of communicable diseases manual. 18th ed. Washington, DC: American Public Health Association; 2004, p. 2756.

13. Ramalingaswami V. Plague in India. Nat Med 1995;1:1237-1239.

14. Bertherat E, Bekhoucha S, Chougrani S, Razik F, Duchemin JB, Houti L, et al. Plague reappearance in Algeria after 50 years, 2003. Emerg Infect Dis 2007;13:1459-1462.

15. Human plague in 2000 and 2001. Wkly Epidemiol Rec 2003;78:130135.

16. Esamaeili S, Azadmanesh K, Naddaf SR, Rajerison M, Carniel E, Mostafavi E. Serologic survey of plague in animals, Western Iran. Emerg Infect Dis 2013;19:1549-1551.

17. World Health Organization. Media centre: plague; 2014 [cited 2016 Aug 5]. Available from: http://www.who.int/mediacentre/factsheets/ fs267/en/.

18. Boisier P, Rahalison L, Rasolomaharo M, Ratsitorahina M, Mahafaly M, Razafimahefa M, et al. Epidemiologic features of four successive annual outbreaks of bubonic plague in Mahajanga, Madagascar. Emerg Infect Dis 2002;8:311-316.

19. Cabanel N, Leclercq A, Chenal-Francisque V, Annajar B, Rajerison M, Bekkhoucha S, et al. Plague outbreak in Libya, 2009, unrelated to plague in Algeria. Emerg Infect Dis 2013;19:230-236.

20. Brett-Crowther M. Contagion: how commerce has spread disease. Int J Environ Stud 2013;70:681-686.

21. Baltazard M. The epidemiological research and its evolution. The example of teamwork on the plague. Bull lnst Pasteur 1969;67:235262 (French).

22. Baltazard M, Bahmanyar M, Mostachfi P, Eftekhari M, Mofidi C. Research on plague in Iran. Bull World Health Organ 1960;23:141155 (French).

23. Dols MW. The black death in the middle east. Princeton: Princeton University Press; 1977, p. 110-125.

24. Karimi Y. Plague and its epidemiology. 1st ed. Tehran: Pasteur Institute of Iran; 1976, p. 55-84 (Persian).

25. Karimi P. Discovery of a new focus of zoonotic plague in the eastern Azarbaidjan region of Iran. Bull Soc Pathol Exot Filiales 1980;73:2835 (French).

26. Seyf A. Iran and the great plague, 1830-1831. Stud Islam 1989. doi: http://dx.doi.org/10.2307/1596071

27. Tholozan JD. Two small outbreaks of plague in Khorassan. CR Acad Sci 1882; 94:114-117 (French).

28. Procopius. History of the wars, books I and II [cited 2016 Aug 25]. Available from: http://www.gutenberg.org/files/16764/16764-h/16764h.htm.

29. Smith CA. Plague in the ancient world: a study from Thucydides to Justinian;1996 [cited 2016 Aug 15]. Available from: http://www.loyno.edu/ history/journal/1996-7/documents/PlagueintheAncientWorld AStudyfromThucydidestoJustinian.pdf.

30. Zarrinkoub A. History the Iranian people. Tehran: Amirkabir; 2006, 110-128 (Persian).

31. Bray RS. Armies of pestilence: the impact of disease on history. Cambridge: James Clarke \& Co.; 2004, p. 64-81.

32. Joukar F, Besharati S, Mirpour H, Mansour-Ghanaei F. Hepatitis C and hepatitis B seroprevalence and associated risk factors in hemodialysis patients in Guilan province, north of Iran: HCV and HBV seroprevalence in hemodialysis patients. Hepat Mon 2011;11:178-181.

33. Dols MW. Plague in early Islamic history. J Am Orient Soc 1974;94: 371-383.

34. Russell JC. That earlier plague. Demography 1968;5:174-184.

35. Petrie GF, Todd RE. A report on plague investigations in Egypt. J Hyg (Lond) 1924;23:117-150.

36. Polo M, Masefield J. The travels of Marco Polo, the Venetian; 1908 [cited 2016 Aug 10]. Available from: https://archive.org/stream/marcopolo00polouoft/marcopolo00polouoft_djvu.txt.

37. Tadjbakhsh H. History of veterinary medicine and medicine in Iran. Tehran: Tehran University Publications; 2001, p. 231-264 (Persian).

38. Kohn GC. Encyclopedia of plague and pestilence: from ancient times to the present. 3rd ed. New York: Facts on File; 2007, p. 42-68.

39. Khajehkazemi R, Osooli M, Sajadi L, Karamouzian M, Sedaghat A, Fahimfar N, et al. HIV prevalence and risk behaviours among people who inject drugs in Iran: the 2010 National Surveillance Survey. Sex Transm Infect 2013;89 Suppl 3:iii29- iii32.

40. Sarrami-Forooshani R, Das SR, Sabahi F, Adeli A, Esmaeili R, Wahren $\mathrm{B}$, et al. Molecular analysis and phylogenetic characterization of HIV in Iran. J Med Virol 2006;78:853-863.

41. Seyf A. The plague of 1877 and the economy of Gilan. Iran 1989;27: 81-86.

42. Théodoridès J. Histoire de la medicine [cited 2016 Aug 10]. Available from: http://www.pathexo.fr/documents/articles-bull/T91-1MR96-127.pdf(French).

43. Schlimmer JL. Medical and pharmaceutical terminology alphabetical French-Persian with English and German translations of French terms. Indication of provenance of major animal and plant products. Details on the new field of several important minerals; on the main mineral waters; on native therapy and the most interesting and unique endemic diseases of the inhabitants of Persia. Teheran: Lithographie d'Ali Gouli Khan; 1874, p. 212-234 (French).

44. Floor WM. Public health in Qajar Iran. Washington, DC: Mage Publishers; 2004, p. 21-24.

45. Azizi MH, Azizi F. A history of the human plague in Iran. Arch Iran Med 2010;13:563-569.

46. Theodorides J. Tholozan and Persia. Hist Sci Med 1998;32:287-296 (French).

47. Kashani-Sabet F. City of the dead: the frontier polemics of quarantines in the Ottoman Empire and Iran. Comp Stud S Asia Afr Middle East 1998;18:51-58.

48. Neligan AR. Public health in Persia. 1914-24. Lancet 1926;207:742744.

49. Jones S. British India steamers and the trade of the Persian Gulf, 1862- 
1914. Great Circle 1985;7:23-44.

50. Karimi Y. Natural preservation of plague in soil. Bull Soc Pathol Exot Filiales 1963;56:1183-1186 (French).

51. Tabatabaei SM, Zahraei SM, Ahmadnia H, Ghotbi M, Rahimi F. Principles of disease prevention and surveillance. 2nd ed. Tehran: Ministry of Health and Medical Education of Iran; 2007, p. 61-75 (Persian).

52. Baltazard M, Karimi Y, Eftekhari M, Chamsa M, Mollaret HH. The interepizootic preservation of plague in an inveterate focus. working hypotheses. Bull Soc Pathol Exot Filiales 1963;56:1230-1245 (French).

53. Baltazard M, Bahmanyar M, Seydian B, Pournaki R. Resistance to the plague by certain wild rodent species. I. Limitation to the epizootic process. 1963. Bull Soc Pathol Exot 2004;97 Suppl:55-59 (French).

54. Baltazard M, Karimi Y. Systematic study of a mesofocus of wild plague in Iranian Kurdistan. IV. The start of a new epizootic period. Bull Soc Pathol Exot Filiales 1963;56:1161-1168 (French).

55. Baltazard M, Bahmanyar M, Mofidi C, Seydian B. Kurdistan plague focus. Bull World Health Organ 1952;5:441-472 (French).

56. Pollitzer R. Plague. Geneva: World Health Organization; 1954, p. 409-482.

57. Ben-Ari T, Neerinckx S, Gage KL, Kreppel K, Laudisoit A, Leirs H, et al. Plague and climate: scales matter. PLoS Pathog 2011;7:e1002160.

58. Schmid BV, Büntgen U, Easterday WR, Ginzler C, Walløe L, Bramanti B, et al. Climate-driven introduction of the Black Death and successive plague reintroductions into Europe. Proc Natl Acad Sci U S A 2015;112:3020-3025.

59. Assmar M, Nekouei H. A review of plague in the Kurdistan. In: Proceedings of 1st Congress of the Infectious Diseases in Wars and Disasters, Tehran: National Medical Society of Basij; 1996, p. 20 (Persian).

60. Motin VL, Georgescu AM, Elliott JM, Hu P, Worsham PL, Ott LL, et al. Genetic variability of Yersinia pestis isolates as predicted by PCR-based IS100 genotyping and analysis of structural genes encoding glycerol-3-phosphate dehydrogenase (glpD). J Bacteriol 2002; 184:1019-1027.

61. Li Y, Cui Y, Hauck Y, Platonov ME, Dai E, Song Y, et al. Genotyping and phylogenetic analysis of Yersinia pestis by MLVA: insights into the worldwide expansion of Central Asia plague foci. PLoS One 2009;4:e6000.

62. Wiechmann I, Grupe G. Detection of Yersinia pestis DNA in two early medieval skeletal finds from Aschheim (Upper Bavaria, 6th century A.D.). Am J Phys Anthropol 2005;126:48-55.

63. Morelli G, Song Y, Mazzoni CJ, Eppinger M, Roumagnac P, Wagner $\mathrm{DM}$, et al. Yersinia pestis genome sequencing identifies patterns of global phylogenetic diversity. Nat Genet 2010;42:1140-1143.

64. Hackett LW. Expert Committee on Plague, second report: WHO technical report series No. 74. 13 pp. Available also in French edition. WHO, Geneva, 1953. Distributed by Columbia University Press, International Documents Service, 2960 Broadway, New York 27, New York. Price \$.10, 9 d., Fr.fr. 30.00, Sw. Fr. 0.40. Am J Trop Med Hyg 1954;3:581-582.

65. Faulde MK. Vector-borne infectious diseases in Afghanistan [cited 2016 Aug 10]. Available from: http://www.acq.osd.mil/eie/afpmb/ docs/dveps/Afghanistan.pdf.

66. Leslie T, Whitehouse CA, Yingst S, Baldwin C, Kakar F, Mofleh J, et al. Outbreak of gastroenteritis caused by Yersinia pestis in Afghanistan. Epidemiol Infect 2011;139:728-735.

67. Khalifa HA. Rice M. Bahrain through the ages: the archaeology. New York: Routledge \& Kegan Paul; 1986, p. 67-71.

68. Agius DA. Seafaring in the Arabian Gulf and Oman: the people of the dhow. Hoboken: Taylor and Francis; 2012, p. 11-12, 143.

69. Hubbard CA. Fleas and plague in Iraq and the Arab world. Baghdad:
Iraq Natural History Museum; 1958, p. 64-88.

70. Magelssen WC, Vouros C. Turkey. Report of plague in Beirut, Syria. Public Health Rep 1900;15;2126-2127.

71. Elgood C. A medical history of Persia, and the eastern caliphate, from the earliest times until the year A.D. 1932. Cambridge: Cambridge University Press; 1951, p. 132-168.

72. Heggs TB. Pneumonic plague in Iraq. Trans R Soc Trop Med Hyg 1924;18:45-49.

73. Arbaji A, Kharabsheh S, Al-Azab S, Al-Kayed M, Amr ZS, Abu Baker M, et al. A 12-case outbreak of pharyngeal plague following the consumption of camel meat, in north-eastern Jordan. Ann Trop Med Parasitol 2005;99:789-793.

74. British Delegate on the Constantinople Board of Health. The outbreaks of plague in Jaddah and Trebizond. Lancet 1906;168:525-526.

75. Bin Saeed AA, Al-Hamdan NA, Fontaine RE. Plague from eating raw camel liver. Emerg Infect Dis 2005;11:1456-1457.

76. Memish ZA, McNabb SJ, Mahoney F, Alrabiah F, Marano N, Ahmed QA, et al. Establishment of public health security in Saudi Arabia for the 2009 Hajj in response to pandemic influenza A H1N1. Lancet 2009;374:1786-1791.

77. Tamaddoni A, Mohammadzadeh I, Ziaei O. Seroprevalence of HCV antibody among patients with beta-thalassemia major in Amirkola Thalassemia Center, Iran. Iran J Allergy Asthma Immunol 2007;6:41.

78. Conrad LI. Epidemic disease in central Syria in the late sixth century some new insights from the verse of Hassan ibn Thabit. Byz Mod Greek Stud 1994;18:12-59.

79. Drancourt M, Raoult D. Molecular insights into the history of plague. Microbes Infect 2002;4:105-109.

80. Morony MG. For whom does the writer write? In: Little LK, editor. Plague and the end of antiquity: the pandemic of 541-750. New York: Cambridge University Press; 2007, p.59-86.

81. Simpson WJ. A treatise on plague: dealing with the historical, epidemiological, clinical, therapeutic and preventive aspects of the disease. Cambridge: Cambridge University Press; 2010, p. 38.

82. Bahmanyar M. Human plague episode in the district of Khawlan, Yemen. Am J Trop Med Hyg 1972;21:123-128.

83. Lotfy WM. Plague in Egypt: disease biology, history and contemporary analysis: a mini review. J Adv Res 2015;6:549-554.

84. Hussein AG. Changes in the epidemiology of plague in Egypt, 18991951. Bull World Health Organ 1955;13:27-48.

85. Panagiotakopulu E. Pharaonic Egypt and the origins of plague. J Biogeogr 2004;31:269-275.

86. Malek MA, Bitam I, Drancourt M. Plague in Arab Maghreb, 19402015: a review. Front Public Health 2016;4:112.

87. Misonne X. A natural focus of plague in Libya. Ann Soc Belg Med Trop 1977; 57:163-168 (French).

88. Cabanel N, Leclercq A, Chenal-Francisque V, Annajar B, Rajerison M, Bekkhoucha S, et al. Plague outbreak in Libya, 2009, unrelated to plague in Algeria. Emerg Infect Dis 2013;19:230-236.

89. Tarantola A, Mollet T, Gueguen J, Barboza P, Bertherat E. Plague outbreak in the Libyan Arab Jamahiriya. Euro Surveill 2009;14:pii= 19258.

90. Pollitzer R. Plague studies. 1. A summary of the history and survey of the present distribution of the disease. Bull World Health Organ 1951;4:475-533.

91. Benedictow OJ. Morbidity in historical plague epidemics. Popul Stud (Camb) 1987;41:401-431.

92. Davis DH. Plague in Africa from 1935 to 1949; a survey of wild rodents in African territories. Bull World Health Organ 1953;9:665-700.

93. Gallagher NE. Medicine and power in Tunisia, 1780-1900. Cambridge: Cambridge University Press; 2002, p. 24-36. 
94. Wassilieff A. Rodents and fleas of Tunisia and their role in the spread of plague. IV. The comparative susceptibility of various Tunisian rodents exposed to plague. Arch Inst Pasteur Tunis 1933;22:443-476 (French).

95. Brisou JF. The occurence of a plague epidemic at Sidi Abdallah-Ferryville in 1944-1945. Hist Sci Med 1995;29:337-341 (French).

96. World Health Organization. WHO expert committee on plague: fourth report.; 1970 [cited 2016 Aug 4]. Available from: http://apps.who.int/ iris/bitstream/10665/40775/1/WHO_TRS_447.pdf.

97. Ozsan K, Akyay N. Epidemiological studies of the plague epidemic in
Akcakale in 1947. Turk Hij Tecr Biyol Derg 1954;14:285-287 (Turkish).

98. Pollitzer R. A review of recent literature on plague. Bull World Health Organ 1960;23:313-400.

99. Bitam I, Baziz B, Rolain JM, Belkaid M, Raoult D. Zoonotic focus of plague, Algeria. Emerg Infect Dis 2006;12:1975-1977.

100. Bitam I, Ayyadurai S, Kernif T, Chetta M, Boulaghman N, Raoult D, et al. New rural focus of plague, Algeria. Emerg Infect Dis 2010;16: 1639-1640. 